\title{
Usefulness of Preoperative Diagnosis with Magnetic Resonance Imaging for Conservative Surgery in Paget's Disease of the Breast
}

\author{
Fabio Corsi $^{\mathrm{a}}$ Alessandra Sartani $^{\mathrm{a}}$ \\ Andrea Fontana $^{a}$ Diego Foschi ${ }^{a}$ \\ a Department of Surgery, L. Sacco Hospital, \\ ${ }^{\mathrm{b}}$ Department of Radiology, University of Milan, Italy
}

\section{Key Words}

Paget's disease - Breast carcinoma - Conservative surgery

\section{Summary}

Background: Paget's disease (PD) of the breast is a relatively rare condition (incidence 1-3\%) among primary breast cancers [6]. It presents with suggestive symptoms like erythema, nipple bleeding and ulceration. Patient and Methods: A 76-year-old woman was followed up for cancer of the left breast that had been operated 10 years before. During her annual check, a lesion suggestive of PD was detected. Mammography and ultrasound were performed, without evidence of a new breast lesion. In consideration of a possible underestimation of the real extent of the disease, we performed magnetic resonance imaging (MRI). Results: MRI showed an irregularly shaped tissue infiltrating the external side of the right breast. The pathologically bright signal involved the nipple and deformed the areolar skin. The characteristics of the increased signal were typical of a hypervascular invasive pattern and for tumoral neoangiogenesis. We performed a mastectomy with sentinel lymph node (SLN) biopsy, with evidence of a DIN 3 carcinoma associated with PD of the nipple at the final pathology report. Conclusion: The MRI was instrumental for the assessment of the existence and extent of malignant disease in a patient with PD but without a palpable lesion detectable with negative ultrasound and mammography.

\section{Introduction}

Paget's disease (PD) of the breast is usually suspected because of symptoms and signs such as erythema, eczema, ulceration, bleeding and itching involving the nipple or the areola. In most cases, the existence of an underlying tumor is confirmed via mammography and/or breast ultrasound. While in the past mastectomy was the gold standard surgical proce-
Silvia Alineri ${ }^{\mathrm{b}}$ Matteo Uccelli ${ }^{\mathrm{a}}$

Schlüsselwörter

Paget-Krankheit · Mammakarzinom · Operation, konservative

\section{Zusammenfassung}

Hintergrund: Die Paget-Krankheit (PD) der Brust ist verglichen mit allen primären Brustkrebsarten eine relative seltene Krankheit (Inzidenz von 1-3\%) [6]. Sie tritt mit Symptomen wie Erythema, Brustwarzenblutungen und Geschwüren auf. Patientin und Methoden: Eine 76-jährige Frau wurde aufgrund eines Mammakarzinoms in der linken Brust, das 10 Jahre zuvor operiert worden war, nachbehandelt. Bei ihrer jährlichen Untersuchung wurde eine Läsion entdeckt, die auf PD hindeutete. Eine Mammographie und eine Ultraschalluntersuchung wurden durchgeführt, ohne dass eine neue Läsion in der Brust nachgewiesen werden konnte. In Anbetracht einer möglichen Unterschätzung des tatsächlichen Ausmaßes der Krankheit wurde eine Magnetresonanztomografie (MRT) durchgeführt. Ergebnisse: Die MRT zeigte unregelmäßig geformtes Gewebe, das die Außenseite der rechten Brust infiltrierte. Das pathologisch helle Signal betraf die Brustwarze und verformte die Haut des Warzenhofes. Die charakteristischen Eigenschaften des verstärkten Signals waren typisch für eine hypervaskuläre invasive Struktur und für tumorartige Neoangiogenese. Wir führten eine Mastektomie zusammen mit einer Sentinel-Lymphknoten-Biopsie durch, wobei sich beim abschließenden Pathologiebefund Hinweise auf ein DIN-3-Karzinom und eine PD der Brustwarze ergaben. Schlussfolgerung: Die MRT war hilfreich bei der Feststellung der Existenz und des Ausmaßes einer malignen Erkrankung bei einer Patientin, die PD hatte, aber keine fühlbaren Läsion, die mit Ultraschall oder Mammographie feststellbar gewesen wäre.

dure, recent studies recommend breast-conserving surgery whenever possible [1]. Therefore, accurate preoperative assessment is of utmost importance to make the appropriate decision. A recent review stated that, although breast conservation is an attractive option in patients with PD, mammography and physical exam may underestimate the presence and extent of the underlying disease [2,3].

\begin{tabular}{ll}
\hline KARGER & ๑ 2010 S. Karger GmbH, Freiburg \\
Fax +497614520714 & Accessible online at: \\
Information@Karger.de & www.karger.com/brc \\
www.karger.com &
\end{tabular}




\section{Case Report}

A 76-year-old woman was followed up annually in an outside institution because of an in situ lesion of the left breast operated 10 years before. No additional treatment had been recommended. Recently, during her annual check, a squamous-erythematous lesion of the right nipple was detected, but no mass was palpable. Mammography, performed prior to the visit, did not show any evidence of a suspicious lesion. Nevertheless, an ultrasound of the breast was performed and no lesion was detected. PD of the breast was suspected and a full-thickness biopsy of the nipple and areola was performed. The pathology report of the specimen yielded typical findings of the disease and the diagnosis of PD was therefore confirmed. The patient was referred to our department for surgery. In consideration of a possible underestimation of the real extent of the disease, we performed magnetic resonance imaging (MRI)

To image the breast, we use a dedicated double-breast surface coil allowing simultaneous imaging of both entire breasts. The patient is in the prone position with arms raised to reduce fold-over artifacts. A venous line $(18-20 \mathrm{G})$ is placed into an antecubital vein. We perform breast MRI at $1.0 \mathrm{~T}$ (Philips Gyroscan INTERA). Prior to the dynamic series, we obtain a T2W turbo spin echo (TSE) on the axial plane, with the geometric parameters corresponding to those of the subsequent dynamic series. In our experience, the $\mathrm{T} 2 \mathrm{~W}$ images improve the detection of inflammatory disease, cystic lesions or interstitial edema after radiation therapy. We add a fat saturation (FAT-SAT) T2 transverse imaging (fig. 1). Both series produce images with $4 \mathrm{~mm}$ thickness, without inter-slice gap. Then, we obtain a total of 10 dynamic scans (3D water only selection (WATS) technique) in series, i.e. 1 pre-contrast and 9 times after-bolus injection of $0.1 \mathrm{mmol} / \mathrm{kg}$ gadolinium (figs. 2, 3). Each dynamic scan consists of $21 \mathrm{sec}-$ tions, with a slice thickness of $4 \mathrm{~mm}$. In our experience, multiplanar reconstructions (MPRs) and maximum intensity projection (MIP) are complementary (but not always necessary) imaging methods to elucidate the lesion's location, for example in the sagittal or coronal planes (fig. 4). As regards the kinetic analysis, we place a small region of interest (ROI) in the lesion to obtain an 'enhancement curve' by plotting the lesion signal intensity over time. In this particular case, we obtained a 'plateau'-type curve, in which we get an initial enhancement upstroke abruptly cut off by a signal plateau in the intermediate and late post-contrast period (fig. 5). This particular shape of the curve increases suspicion of malignancy of a lesion, with a statistical recurrence of 3:2 of malignant versus benign.

In consideration of the extent of the disease, the age of the patient and her consent, a mastectomy was performed with sentinel lymph node (SLN) biopsy. Intraoperative analysis of the SLNs was performed and showed the absence of metastatic malignant cells.

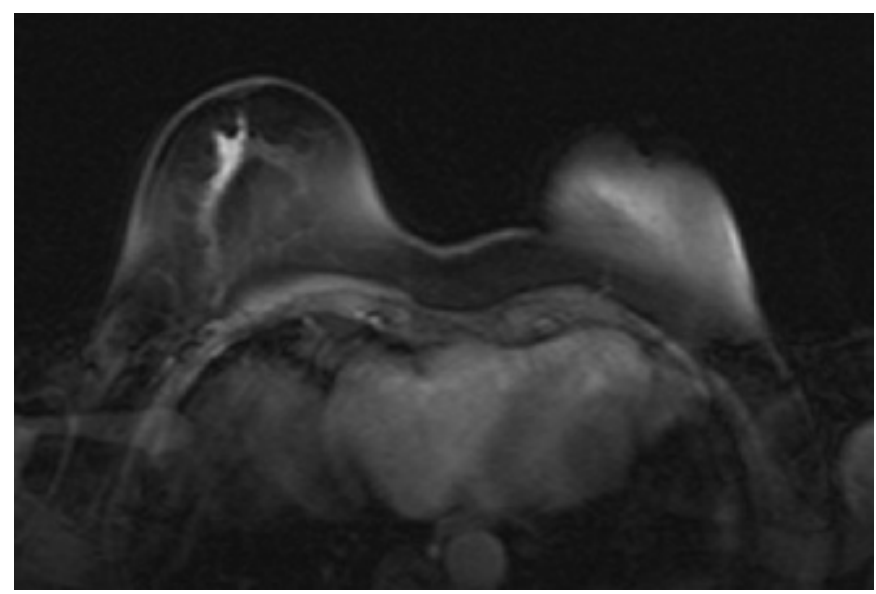

Fig. 2. MR axial $T 1 \mathrm{~W}$ image after gadolinium-diethylene triamine pentaacetic acid (DTPA) injection reveals a highly suspicious enhanced tissue with indistinct margins and an inhomogeneous internal architecture.
The final pathology report revealed the presence of high-grade in situ ductal carcinoma (DIN 3) associated with PD of the nipple. The absence of metastatic involvement of the SLNs was confirmed. Immunohistochemistry demonstrated the absence of estrogen and progesterone receptor staining. The Ki67 index was 30\%. The post-operative period was uneventful and the patient was discharged on the third post-operative day. No additional treatment was recommended.

\section{Discussion}

The existence of an underlying lesion in the breast in patients with PD is frequent. In a series of 70 patients [3], the lesion

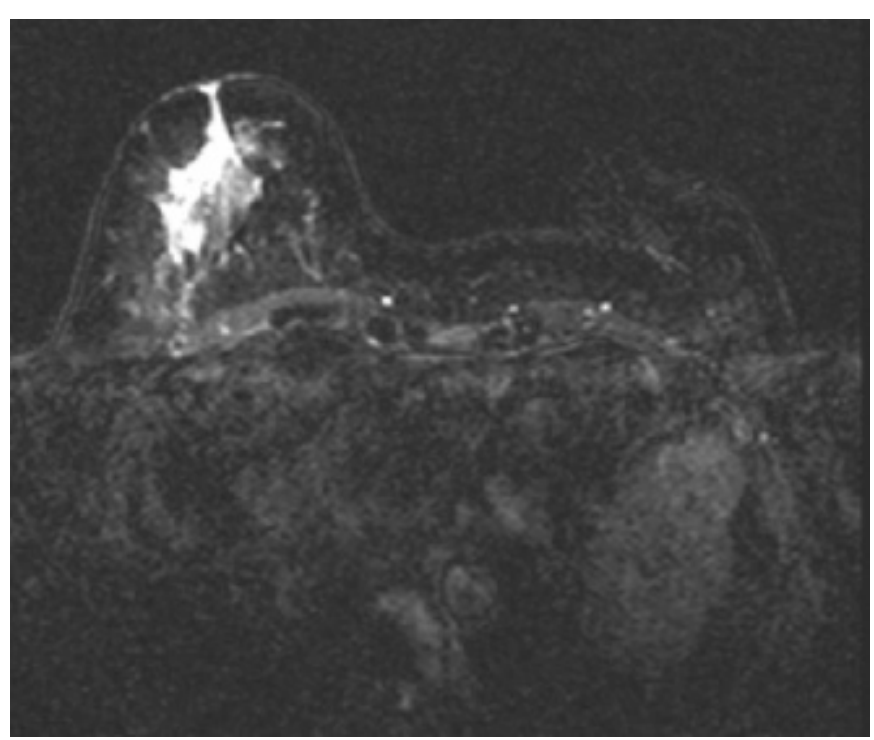

Fig. 1. A FAT-SAT T2-weighted transverse image showing an irregularly shaped tissue infiltrating the external side of the right breast. The pathologically bright signal involves the nipple and deforms the areolar skin.

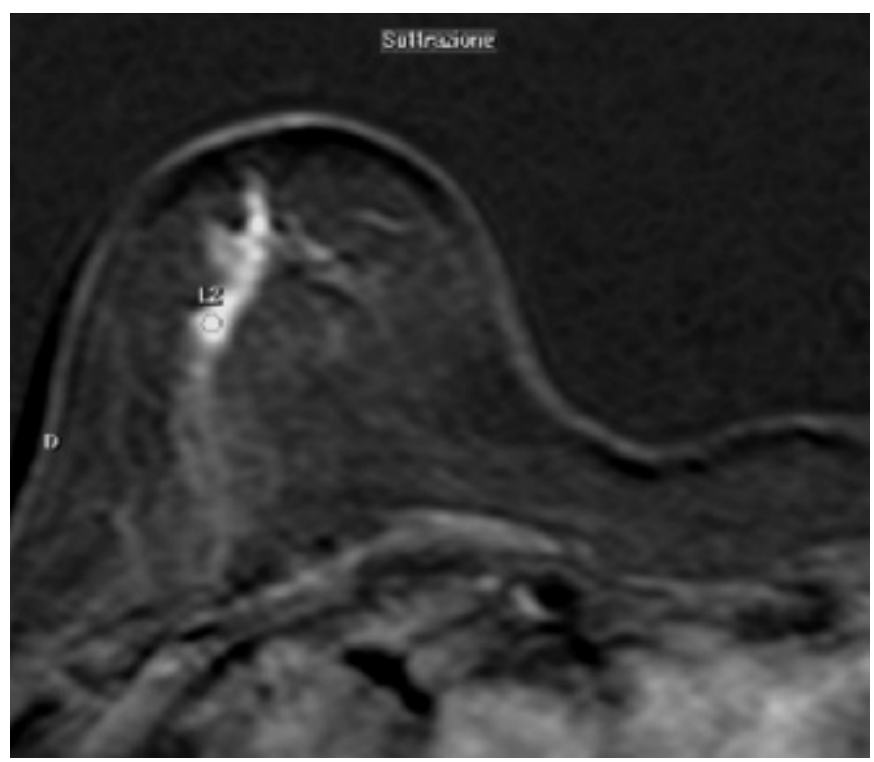

Fig. 3. The corresponding early post-contrast subtracted image of the dynamic series shows a dermal thickening, interstitial edema and strong cutaneous enhancement in accordance with an inflammatory cancer. 
was present in $98.5 \%$. The authors report a similar rate in the literature. Other reports provide different numbers. There is no doubt that an occult lesion is frequently present and must be looked for, even in the absence of a palpable mass or in the presence of a negative mammogram. In other series, the authors recommended the use of ultrasound and MRI especially in young women (age $<50$ years) [4-6]. In non-invasive breast cancer, MRI has a sensitivity of $95 \%$ compared to $70 \%$ of mammography.

The most frequently reported symptoms of PD are nipple discharge, scaling or eczematous changes, like erythema, eczema or ulceration; the eczematous reaction almost always appears first on the nipple, subsequently spreading to the areola. Some women have an itching or burning sensation. Fluid (discharge) may leak from the abnormal area of cells. Our patient had no palpable mass and a negative mammogram, but diagnosis of PD was obtained via biopsy. An effort to determine the existence and extent of an underlying carcinoma with ultrasound failed while MRI resulted in a more precise diagnosis, ultimately permitting to make a therapeutic decision prior to the procedure.

MRI can also be useful in case of breast biopsy and/or wire localization, especially if a conservative surgical procedure is being considered. In this case, a magnetic resonance (MR)guided breast biopsy was not performed because the distance of the lesion from the nipple-areolar complex did not allow a conservative procedure.

In conclusion, the MRI was instrumental for the assessment of the existence and extent of malignant disease in a patient with PD but without a palpable lesion and with negative imaging procedures. We agree with the studies that recommend breast-conserving surgery in PD when feasible, but we underline the importance of preoperative assessment of the extent of occult malignancy. We therefore suggest the use of MRI whenever a conserving surgical procedure is considered, in order to offer the patient a better cosmetic result and an oncologically adequate procedure.

\section{Conflict of Interest}

The authors certify that there is no conflict of interest with any financial organization regarding the material discussed in the manuscript.

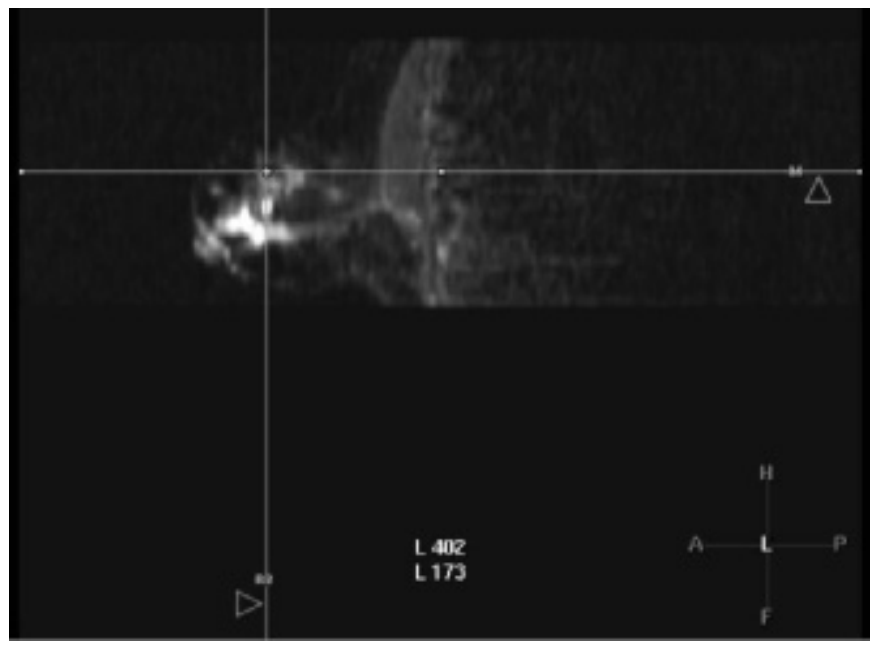

Fig. 4. MIP on the sagittal plane that shows the lesion's deepness.
Fig. 5. An ROI focalizing on the dermal thickening is used to demonstrate the enhancement of the lesion; the shape of the curve is typical of an inflammatory cancer.
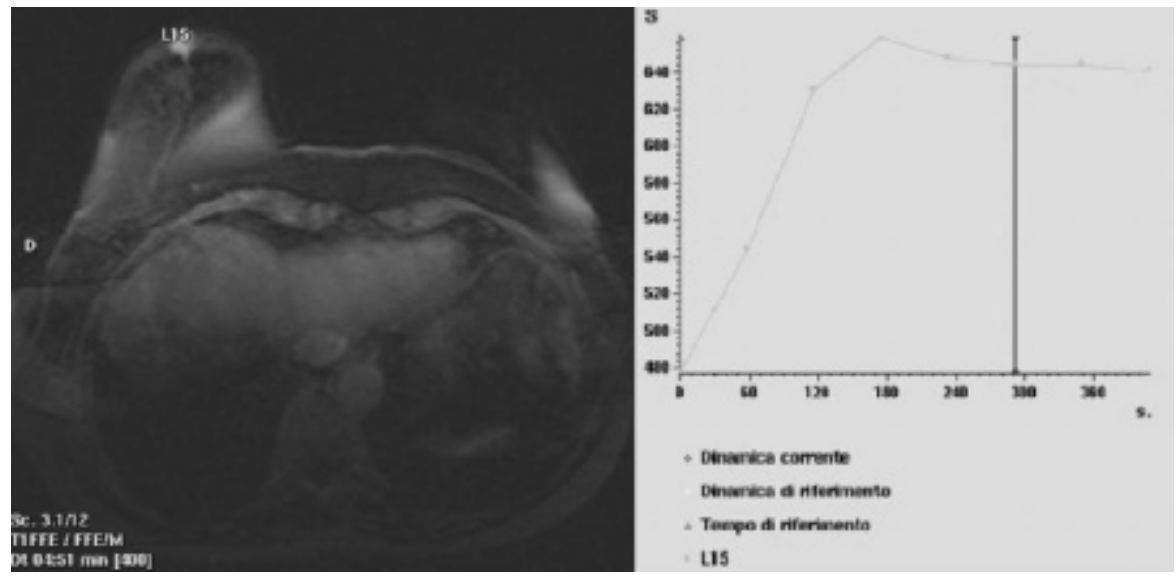

\section{References}

1 Bijker N, Rutgers EJ, Duchateau L, et al.: Breast conserving therapy for Paget's disease of the nipple: a prospective European Organization for Research and Treatment of Cancer study of 61 patients. Cancer 2001;91:472-477.

2 Shaheen Z, Gouri P, Karthik G, et al.: Paget's disease of the breast: accuracy of preoperative assessment. Breast Cancer Res Treat 2007;102:137-142.

3 Kothari A, Beechey-Newman N, Hamed H, et al.: Paget disease of the nipple: a multifocal manifestation of higher-risk disease: Cancer 2002;95:1-7.

4 Ashikari R, Park K, Huvos AG, et al.: Paget's disease of the breast. Cancer 1970;26:287-292.

5 Yim JH, Wick MR, Philpot GW, et al.: Underlying pathology in mammary Paget's disease. Ann Surg Oncol 1997;4:287-292. 